\title{
Physiological Properties and Salmonella Growth Inhibition of Probiotic Bacillus Strains Isolated from Environmental and Poultry Sources
}

\author{
Anita Menconi, Marion J. Morgan, Neil R. Pumford, Billy M. Hargis, and Guillermo Tellez \\ Department of Poultry Science, University of Arkansas, Fayetteville, AR 72701, USA \\ Correspondence should be addressed to Guillermo Tellez; gtellez@uark.edu
}

Received 15 March 2013; Accepted 10 May 2013

Academic Editor: Ramakrishna Nannapaneni

Copyright (c) 2013 Anita Menconi et al. This is an open access article distributed under the Creative Commons Attribution License, which permits unrestricted use, distribution, and reproduction in any medium, provided the original work is properly cited.

The objective of the present study was to describe the physiological properties of seven potential probiotic strains of Bacillus spp. Isolates were characterized morphologically, biochemically, and by $16 \mathrm{~S}$ rRNA sequence analyses for identification. Tolerance to acidic $\mathrm{pH}$, high osmotic concentrations of $\mathrm{NaCl}$, and bile salts were tested. Isolates were also evaluated for their ability to metabolize different carbohydrates sources. The antimicrobial sensitivity profiles were determined. Inhibition of gastrointestinal Salmonella colonization in an avian model was also evaluated. Five strains of Bacillus were tolerant to acidic conditions ( $\mathrm{pH} 2.0$ ) and all strains were tolerant to a high osmotic pressure $(\mathrm{NaCl}$ at $6.5 \%)$. Moreover, all strains were able to tolerate concentration of $0.037 \%$ bile salts after $24 \mathrm{~h}$ of incubation. Three strains were able to significantly reduce Salmonella Typhimurium levels in the crop and in the ceca of broiler-type chickens. Among the 12 antibiotics tested for antibiotic resistance, all strains were resistant to bacitracin and susceptible to gentamycin, neomycin, ormethoprim, triple sulfa, and spectinomycin. Bacterial spore formers have been shown to prevent gastrointestinal diseases in animals and humans. The results obtained in this study show important characteristics to be evaluated when selecting Bacillus spp. candidates to be used as probiotics.

\section{Introduction}

Probiotics have been commercialized for both animal and human uses. Probiotics for humans use are subject to minimal restrictions and come in many different forms. Probiotics in animal feed have been used for the prevention of gastrointestinal infections, with a wide use in poultry and aquaculture productions [1-6].

Diarrhea is one of the major side effects of chemotherapy in cancer treatments and has been associated with increased morbidity, mortality, increased treatment costs, and restrictions related to the ability to deliver full doses of chemotherapy $[7,8]$. Enterocyte proliferation in the intestinal mucosa and the intestinal microflora can be directly harmed by the effect of chemotherapeutic agents as well as radiation, often causing bacterial translocation, malabsorption, and/or diarrhea $[8,9]$. Therefore, in order to reduce systemic bacterial diseases, high doses of broad spectrum antibiotics are usually used in cancer patients undergoing chemotherapy or radiation therapy. The disruption of the beneficial intestinal microflora is a common consequence to this type of treatment, which may lead to the colonization of opportunistic pathogenic bacteria such as Salmonella spp. $[10,11]$ and Clostridium difficile $[12,13]$. Although the most common types of probiotics available are based on lactic acid bacteria (LAB), there are other potentially beneficial microorganisms that are not normally found in the gastrointestinal tract (GIT) such as Saccharomyces boulardii or Bacillus spp. For example, Saccharomyces boulardii has been shown to prevent the recurrence of Clostridium difficile-induced pseudomembranous colitis [14] as well as Escherichia coli infections [15]. Sporeforming bacteria such as Bacillus subtilis, B. megaterium, $B$. licheniformis, Paenibacillus polymyxa, and B. clausii have also been used as probiotics in humans [1].

Many studies have shown that either strains of live bacteria or active spores can efficaciously reach the intestine, preventing colon carcinogenesis $[16,17]$. Moreover, they can suppress the development of preneoplastic lesions [18]. These 
microorganisms can also release antimicrobial substances active against Gram-positive bacteria such as Staphylococcus aureus, Enterococcus faecium, and Clostridium difficile and can induce IFN-gamma production and CD4+ T-cell proliferation $[19,20]$. Products containing Bacillus spp. spores are used commercially as probiotics because they have some advantages over the traditional LAB products, for example, the ability to be stored indefinitely in a dry form $[1,4,21,22]$ and the ability to survive baking processes [23].

Current research has shown that Bacillus subtilis spores, after oral ingestion, are immunogenic and are able to disseminate to Peyer's patches and mesenteric lymph nodes [2325]. Three main findings have supported the hypothesis that Bacillus subtilis spores can germinate in the small intestine. First, following oral ingestion in mice, Hoa et al. [26] showed that more Bacillus subtilis spores were excreted after ingestion than initially given. Second, after administration of spores to mice, expressed mRNA of vegetative cells was detected in the GIT by reverse transcription (RT)-PCR [27]. Third, after oral administration of spores to mice, systemic immunoglobulin $G$ was produced against vegetative Bacillus subtilis cells [24]. The above studies indicate that Bacillus spp. spores are not merely present in the intestinal tract as transient bacteria, but they might also have some interaction with the host enterocytes, immunocompetent cells, or with the intestinal microbiota [22].

Identifying desirable physiological properties and the ability to inhibit the growth of pathogenic bacteria are very important when selecting potential candidates to be used as probiotics for humans and animals. In the present study, Bacillus spp. strains, isolated from poultry and environmental sources, were characterized and evaluated for their ability to metabolize different carbohydrate sources, their antibiotic sensitivity profile, and their tolerance to acidic $\mathrm{pH}$, high osmotic concentrations of sodium chloride $(\mathrm{NaCl})$, and bile salts. In addition, inhibition of Salmonella colonization in a well-established avian model was also evaluated.

\section{Materials and Methods}

2.1. Isolation, Biochemical Tests, and Identification of Selected Bacillus Strains. Strains of Bacillus spp., laboratory identified as NP122, AM0904, B2, RW41, AM0902, AM1109A, and AM1109B, were isolated from environmental and poultry sources as described by Wolfenden et al. [28]. Biochemical evaluation tests as well as identification for these seven selected strains were carried out using a bioMerieux API $50 \mathrm{CHB}$ test kit (catalog number 50430, bioMerieux, Marcy l'Etoile, France). The identification procedure, which followed the manufacturer's instructions, was also important to confirm generally recognized as safe (GRAS) status of the isolates. Besides the biochemical identification, 16S rRNA sequence analyses (Microbial ID Inc., Newark, DE, USA) was carried out.

2.2. Bile Salts Tolerance. The method of Gilliland et al. [29], with some modifications, was used to determine bile salt tolerance. Tryptic Soy Broth (TSB) (Becton Dickinson and Co., Sparks, MD, USA) containing 0\%, 0.037\%, 0.075\%, 0.15\%, and $0.3 \%$ of bile salts number 3 (Catalog number 213010, Becton Dickinson and Co., Sparks, MD, USA) was inoculated with $10^{7} \mathrm{cfu} / \mathrm{mL}$ of each potential probiotic strain, after being centrifuged at $3000 \mathrm{~g}$ for 15 minutes and washed three times from their $24 \mathrm{~h}$ growth cultures. Samples were incubated for $24 \mathrm{~h}$ at $37^{\circ} \mathrm{C}$ with shaking at $100 \mathrm{rev} . / \mathrm{min}$. Growth in control (no bile salts) and test cultures was evaluated at 2, 4, and 24 hours by streaking samples on Tryptic Soy Agar (TSA) for presence or absence of growth.

2.3. Antibiotic Resistance. Selected colonies of NP122, AM0904, B2, RW41, AM0902, AM1109A, and AM1109B on TSA plates were inoculated and cultured for $24 \mathrm{~h}$ in TSB at $37^{\circ} \mathrm{C}$. Strains were then sent to a Veterinary Diagnostic Laboratory (University of Arkansas, Division of Agriculture, Fayetteville, AR, USA) for antibiotic sensitivity analysis using the Kirby-Bauer methodology. The diameter of the inhibition zones and the interpretative zone sizes were reported. Twelve antibiotics were tested and their concentrations were reported as shown in Table 5. The results were expressed in terms of resistant, intermediate (somewhat susceptible with zone of inhibition measuring in between of a susceptible and resistant colony), and susceptible.

\subsection{Resistance in Conditions of the Intestinal Tract Evalua-} tion: $p H$, Temperature, and Sodium Chloride. A basal TSB medium was used in these series of in vitro studies. A $24 \mathrm{~h}$ culture of each isolate was used as the inoculum whereby the cells were spun down and resuspended in $0.9 \%$ sterile saline. Then, $100 \mu \mathrm{L}$ of the suspension was inoculated into $10 \mathrm{~mL}$ of TSB of each test tube. Two incubation time points, that is, two and four hours were evaluated for each of the variables ( $\mathrm{pH}$, temperature, and $\mathrm{NaCl}$ ). The rationale for these two points was mainly based on the transit time of food matter in the gastrointestinal tract of poultry. The temperatures tested were 15 and $45^{\circ} \mathrm{C}$. The concentrations of $\mathrm{NaCl}$ tested were 3.5 and $6.5 \%(\mathrm{w} / \mathrm{v})$. The isolates were tested for growth at $\mathrm{pH}$ 2 and 3 . The tubes were incubated with reciprocal shaking, at the specific test temperatures or at $37^{\circ} \mathrm{C}$ for the tests on $\mathrm{pH}$ and concentrations of $\mathrm{NaCl}$. At the time points evaluated, each sample was streaked on TSA for presence or absence of growth, to confirm livability of the strains. The turbidity of each tube was also noted as an indication of growth or nogrowth. Each treatment was tested with triplicate tubes.

2.5. Salmonella Typhimurium In Vivo Growth Inhibition. A poultry isolate of Salmonella enterica subspecies enterica serovar Typhimurium (ST), which had previously been selected for resistance to nalidixic acid (NA - catalog number N-4382, Sigma, St. Louis, MO, USA), was used in all experiments. The amplification and enumeration protocol for this isolate has been described previously [30]. Trials were conducted with day-of-hatch broiler chicks obtained from a local hatchery, with the exception of one trial that was conducted with six- to seven-week-old broiler chickens. In all trials, broiler chickens were randomly $(n=20)$ assigned to untreated control diet or dietary treatment of each Bacillus spp. isolate at $10^{5} \mathrm{cfu} / \mathrm{g}$ of feed for seven days. Broiler chicks 
were housed in brooder batteries or floor pens with food and water ad libitum. At day four, all birds were challenged with $2 \times 10^{5} \mathrm{cfu} \mathrm{ST/bird}$. At seven days, birds were humanely killed by $\mathrm{CO}_{2}$ inhalation and crop, ceca, and cecal tonsils were aseptically harvested. Salmonella recovery procedures have been previously described by our laboratory and were followed with some modifications [30]. All animal handling procedures were in compliance with the Institutional Animal Care and Use Committee (IACUC) at the University of Arkansas.

2.6. Statistical Analysis. Crop and ceca colony-forming units (cfu) data were converted to $\log _{10}$ cfu numbers and then compared using the GLM procedure of SAS [31] with significance reported at $P<0.05$. The incidence of ST recovery within experiments was compared using the chi-square test of independence [32] to determine significant $(P<0.05)$ differences between control and treated group. All values were converted to percent ST reduction comparing treated birds to nontreated birds (control) to be simplified in a single table.

\section{Results and Discussion}

3.1. Biochemical Tests and Identification of Selected Bacillus Strains. As described by Logan and Berkeley [33], the API $50 \mathrm{CHB}$ system is a rapid and accurate test of Bacillus isolate identification, which allows bacterial isolates to be classified according to their ability to ferment 49 different carbohydrates, which are listed in Table 1. Selected Bacillus isolates were tested to evaluate their biochemical profile, and the results are presented in Table 1 . The carbohydrate fermentation pattern was used to identify each isolate's species. Four isolates were characterized as Bacillus subtilis/amyloliquefaciens, and the three remaining isolates were characterized as Bacillus licheniformis, Bacillus pumilus, and Bacillus megaterium (Table 2). Sequence analysis of 16S rRNA is the predominant molecular technology presently available for microbial identification [34]. The $16 \mathrm{~S}$ rRNA analysis matched the biochemical identification results (Table 2).

3.2. Bile Salts Tolerance. In general, tolerance to bile salts has been considered a prerequisite for colonization and metabolic activity of bacteria in the host's intestine [35]. The average concentration of bile salts in the small intestine is around $0.2 \%$ to $0.3 \%$ and may go up to $2 \%(\mathrm{w} / \mathrm{v})$, depending upon the individual and the type and amount of food ingested [36, 37]. Nevertheless, bile levels in the intestine are not constant and are relatively low until ingestion of a fatty meal [38]. The main purpose of bile secretion is to emulsify and dissolve ingested fats [36]. However, bile salts also have bactericidal effects; they can disrupt the lipid membrane, get into the bacterial cell, denature proteins, chelate ions, and damage DNA [36, 39]. According to Begley et al. [38], many studies have shown that bile tolerance is a strain-specific characteristic and the tolerance of various bacterial species cannot be generalized. Also, Gram-positive bacteria seem to be more sensitive to the harmful effects of bile than Gram-negative bacteria [38].
Evaluating bile salts tolerance of the vegetative cells of our selected strains, we found that all strains were able to grow when cultured at $0.037 \%$ bile salts concentration at $2 \mathrm{~h}$, $4 \mathrm{~h}$, and $24 \mathrm{~h}$ of incubation. Six of the vegetative forms of the Bacillus strains tested for bile resistance were not able to survive at the concentrations of $0.075 \%, 0.15 \%$, and $0.3 \%$ of bile salts during the time points evaluated. The isolate B2 was the only one able to survive at $0.075 \%, 0.15 \%$, and $0.3 \%$ at $2 \mathrm{~h}$ of incubation (Table 3 ). These results are in agreement with Barbosa et al. [21] findings, where vegetative cells of Bacillus isolates were very susceptible to bile salts at $0.2 \%$.

Information about the bile tolerance of Gram-positive bacteria is limited. It is important to know that bacterial tolerance to bile in broth assays, as with many physiological stresses, may not reproduce in vivo. Because bile salts form micelles with phospholipids, they may not be free to interact with bacterial cells, and the in vivo antibacterial activity of bile may be lower than that observed in in vitro assays [38]. Exposure to different $\mathrm{pH}$, temperatures, and growth environments may increase bacterial susceptibility to bile or make them more resistant. For example, an exposure of bacteria to low levels of bile salts may increase their tolerance to higher levels [38]. Also, the presence of food in the intestinal tract can affect survival because bacteria may not be exposed to bile due to the formation of microenvironments by the food particles or food constituents, which may bind to bile components, preventing damage to the bacteria [38]. Bile resistance of some isolates is related to the enzyme activity of bile salt hydrolase (BSH) that helps to hydrolyze conjugated bile, reducing its toxic effect [40]. BSH activity has most often been found in microorganisms isolated from animals' intestines or feces [41].

The Bacillus spore, which consists of multiple protective layers, has been described to be very resistant to different physical and chemical conditions [21], and they have been shown to survive at high concentration (usually more than $1 \%)$ of bile salts $[21,36]$. The hypothesis is that Bacillus spp. spores, after ingestion, would germinate in distal parts of the small intestine, where the concentration of bile salts would be lower $[27,36]$. More physiological analyses are necessary to establish the importance of bile tolerance of bacteria in the intestine [38].

3.3. Resistance in Conditions of the Intestinal Tract Evaluation: pH, Temperature, and Sodium Chloride. Probiotic bacteria need to survive the passage through the stomach, where the $\mathrm{pH}$ can be as low as 1.5 to 2.0 [42], and stay alive for $4 \mathrm{~h}$ or more [43], before they move to the intestinal tract. For this reason, the vegetative cells of the isolates were evaluated for conditions similar to those found in the stomach. The isolates AM1109A and B2 were able to survive at $\mathrm{pH} 2$ and $\mathrm{pH} 3$ for $2 \mathrm{~h}$ and $4 \mathrm{~h}$ of exposure. On the other hand, AM0904 and AM1109B did not survive the harsh pH conditions (Table 4). The remaining isolates (NP122, AM 0902, and RW41) were able to survive at $\mathrm{pH} 2$ and $\mathrm{pH} 3$ at only $2 \mathrm{~h}$ of exposure.

According to Ibourahema et al. [44], the bacterial capability to grow at high temperature is a good characteristic as it could be interpreted as indicating an increased rate of growth. Moreover, a high fermentation temperature reduces 
TABLE 1: Metabolization of different carbohydrates sources by selected isolates of Bacillus spp.*

\begin{tabular}{|c|c|c|c|c|c|c|c|}
\hline & NP122 & AM0904 & B2 & RW41 & AM0902 & AM1109A & AM1109B \\
\hline Amidon (starch) & + & + & + & + & - & + & + \\
\hline Amygdalin & + & + & - & + & + & + & + \\
\hline Arbutin & + & + & - & - & + & + & + \\
\hline D-Adonitol & - & - & - & - & - & - & - \\
\hline D-Arabinose & - & - & - & - & - & - & - \\
\hline D-Arabitol & - & - & - & - & - & - & - \\
\hline D-Cellobiose & + & + & + & + & + & + & + \\
\hline D-Fructose & + & + & + & + & + & + & + \\
\hline D-Fucose & - & - & - & - & - & - & - \\
\hline D-Galactose & - & - & - & + & + & - & + \\
\hline D-Glucose & + & + & + & + & + & + & + \\
\hline D-Lactose & - & + & + & + & - & + & + \\
\hline D-Lyxose & - & - & - & - & - & - & - \\
\hline D-Maltose & + & + & + & + & + & + & + \\
\hline D-Manitol & + & + & + & + & + & + & + \\
\hline D-Mannose & + & + & + & + & + & + & + \\
\hline D-Melezitose & - & - & - & - & - & - & - \\
\hline D-Melibiose & - & + & + & + & - & + & + \\
\hline D-Raffinose & - & + & + & + & - & + & + \\
\hline D-Ribose & + & + & + & + & + & + & + \\
\hline D-Saccharose & + & + & + & + & + & + & + \\
\hline D-Sorbitol & + & + & + & + & - & + & + \\
\hline D-Tagatose & - & - & - & + & + & - & - \\
\hline D-Trehalose & + & + & + & - & + & + & + \\
\hline D-Turanose & - & - & - & + & + & - & + \\
\hline Dulcitol & - & - & - & - & - & - & - \\
\hline D-Xylose & - & + & + & + & + & + & + \\
\hline Erythritol & - & - & - & - & - & - & - \\
\hline Esculin (ferric citrate) & + & + & + & + & + & + & + \\
\hline Gentiobiose & + & - & - & + & - & - & - \\
\hline Glycerol & + & + & + & + & + & + & + \\
\hline Glycogen & + & + & + & + & - & + & + \\
\hline Inositol & + & + & + & + & - & + & + \\
\hline Inulin & - & - & - & + & - & - & ND \\
\hline L-Arabinose & + & + & + & + & + & + & + \\
\hline L-Arabitol & - & - & - & - & - & - & - \\
\hline L-Fucose & - & - & - & - & - & - & - \\
\hline L-Rhamnose & - & - & - & + & - & - & - \\
\hline L-Sorbose & - & - & - & + & - & - & - \\
\hline L-Xylose & - & - & - & - & - & - & - \\
\hline Methyl- $\alpha$ D-glucopyranoside & + & + & + & + & + & + & ND \\
\hline Methyl- $\alpha \mathrm{D}$-mannopyranoside & - & - & - & - & + & - & - \\
\hline Methyl- $\beta$ D-xylopyranoside & - & - & - & - & - & - & - \\
\hline N-Acetylglucosamine & - & - & - & - & + & - & - \\
\hline Potassium 2-Ketogluconate & - & - & - & - & - & - & - \\
\hline Potassium 5-Ketogluconate & - & - & - & - & - & - & - \\
\hline Potassium gluconate & - & - & - & - & - & - & - \\
\hline Salicin & + & + & + & + & + & + & + \\
\hline Xylitol & - & - & - & - & - & - & + \\
\hline
\end{tabular}

* BioMerieux API 50 CHB test kit (catalog no. 50430, bioMerieux, Marcy l'Etoile, France). Symbols: +: growth; -: no growth. ND: not determined. 
TABLE 2: Identification (ID) of Bacillus spp. isolates by bioMerieux API $50 \mathrm{CHB}^{*}$ and $16 \mathrm{~S}$ rRNA sequence analyses** .

\begin{tabular}{lcc}
\hline Bacillus isolates & API 50 CHB identification (\% ID) & 16 S identification (\% ID) \\
\hline NP122 & Bacillus subtilis/amyloliquefaciens (98.2\%) & Bacillus amyloliquefaciens (96\%) \\
AM0904 & Bacillus subtilis/amyloliquefaciens (96.6\%) \\
B2 & Bacillus subtilis/amyloliquefaciens (99.7\%) & Bacillus amyloliquefaciens (99.57\%) \\
RW41 & Bacillus licheniformis (99.9\%) & Bacillus amyloliquefaciens (99.52\%) \\
AM0902 & Bacillus pumilus (99.9\%) & Bacillus licheniformis (98.66\%) \\
AM1109A & Bacillus subtilis/amyloliquefaciens (96.6\%) & Bacillus pumilus (100\%) \\
AM1109B & Bacillus megaterium (75.3\%) & ND \\
\hline
\end{tabular}

* BioMerieux API 50 CHB test kit (catalog no. 50430, bioMerieux, Marcy l’Etoile, France).

** 16 S rRNA sequence analyses (Microbial ID Inc., Newark, DE, USA).

ND: not determined.

TABLE 3: Bacillus spp. isolates bile salt tolerance after 2, 4, and 24 hours of incubation.

\begin{tabular}{lcccccccccccccccc}
\hline \multirow{2}{*}{ Bacillus isolates } & \multicolumn{3}{c}{$0 \%$} & \multicolumn{4}{c}{$0.037 \%$} & \multicolumn{3}{c}{$0.075 \%$} & \multicolumn{3}{c}{$0.15 \%$} & \multicolumn{3}{c}{$0.3 \%$} \\
& $2 \mathrm{~h}$ & $4 \mathrm{~h}$ & $24 \mathrm{~h}$ & $2 \mathrm{~h}$ & $4 \mathrm{~h}$ & $24 \mathrm{~h}$ & $2 \mathrm{~h}$ & $4 \mathrm{~h}$ & $24 \mathrm{~h}$ & $2 \mathrm{~h}$ & $4 \mathrm{~h}$ & $24 \mathrm{~h}$ & $2 \mathrm{~h}$ & $4 \mathrm{~h}$ & $24 \mathrm{~h}$ \\
\hline NP122 & + & + & + & + & + & + & + & - & - & - & - & - & - & - & - \\
AM0904 & + & + & + & + & + & + & - & - & - & - & - & - & - & - & - \\
AM0902 & + & + & + & + & + & + & - & - & - & - & - & - & - & - & - \\
AM1109A & + & + & + & + & + & + & - & - & - & - & - & - & - & - & - \\
AM109B & + & + & + & + & + & + & - & - & - & - & - & - & - & - & - \\
RW41 & + & + & + & + & + & + & - & - & - & - & - & - & - & - & - \\
B2 & + & + & + & + & + & + & + & - & - & + & - & - & + & - & - \\
\hline
\end{tabular}

Symbols: +: tolerant; -: nontolerant.

TABLE 4: Effect of $\mathrm{pH}$, temperature, and sodium chloride $(\mathrm{NaCl})$ on the Bacillus spp. isolates.

\begin{tabular}{|c|c|c|c|c|c|c|c|c|c|c|c|c|}
\hline \multirow{2}{*}{ Bacillus isolates } & \multicolumn{2}{|c|}{$\mathrm{pH} 2$} & \multicolumn{2}{|c|}{$\mathrm{pH} 3$} & \multicolumn{2}{|c|}{$15^{\circ} \mathrm{C}$} & \multicolumn{2}{|c|}{$45^{\circ} \mathrm{C}$} & \multicolumn{2}{|c|}{$3.5 \% \mathrm{NaCl}$} & \multicolumn{2}{|c|}{$6.5 \% \mathrm{NaCl}$} \\
\hline & $2 \mathrm{~h}$ & $4 \mathrm{~h}$ & $2 \mathrm{~h}$ & $4 \mathrm{~h}$ & $2 \mathrm{~h}$ & $4 \mathrm{~h}$ & $2 \mathrm{~h}$ & $4 \mathrm{~h}$ & $2 \mathrm{~h}$ & $4 \mathrm{~h}$ & $2 \mathrm{~h}$ & $4 \mathrm{~h}$ \\
\hline NP122 & + & - & + & - & + & + & + & + & + & + & + & + \\
\hline AM0904 & - & - & - & - & + & + & + & + & + & + & + & + \\
\hline AM0902 & + & + & + & - & + & + & + & + & + & + & + & + \\
\hline AM1109A & + & + & + & + & + & + & + & + & + & + & + & + \\
\hline AM1109B & - & - & - & - & + & + & + & + & + & + & + & + \\
\hline RW41 & + & - & + & - & + & + & + & + & + & + & + & + \\
\hline B2 & + & + & + & + & + & + & + & + & + & + & + & + \\
\hline
\end{tabular}

Symbols: +: tolerant; -: nontolerant.

TABLE 5: Antibiotic sensitivity test* for Bacillus spp. isolates.

\begin{tabular}{lccccccc}
\hline Antibiotics & Concentration & AM0902 & AM1109A & AM1109B & AM0904 & NP122 & RW41 \\
\hline Bacitracin & $10 \mathrm{IUI} / \mathrm{IE} / \mathrm{U}$ & $\mathrm{R}$ & $\mathrm{R}$ & $\mathrm{R}$ & $\mathrm{R}$ & $\mathrm{R}$ & $\mathrm{R}$ \\
Erythromycin & $15 \mu \mathrm{g}$ & $\mathrm{I}$ & $\mathrm{S}$ & $\mathrm{S}$ & $\mathrm{S}$ & $\mathrm{S}$ & $\mathrm{R}$ \\
Gentamycin & $10 \mu \mathrm{g}$ & $\mathrm{S}$ & $\mathrm{S}$ & $\mathrm{S}$ & $\mathrm{S}$ & $\mathrm{S}$ & $\mathrm{S}$ \\
Clindamycin & $2 \mu \mathrm{g}$ & $\mathrm{R}$ & $\mathrm{S}$ & $\mathrm{S}$ & $\mathrm{S}$ & $\mathrm{S}$ & $\mathrm{R}$ \\
Ceftiofur & $30 \mu \mathrm{g}$ & $\mathrm{R}$ & $\mathrm{S}$ & $\mathrm{S}$ & $\mathrm{S}$ & $\mathrm{S}$ & $\mathrm{R}$ \\
Neomycin & $30 \mu \mathrm{g}$ & $\mathrm{S}$ & $\mathrm{S}$ & $\mathrm{S}$ & $\mathrm{S}$ & $\mathrm{S}$ & $\mathrm{S}$ \\
Novobiocin & $5 \mu \mathrm{g}$ & $\mathrm{R}$ & $\mathrm{S}$ & $\mathrm{S}$ & $\mathrm{S}$ & $\mathrm{S}$ & $\mathrm{S}$ \\
Penicillin & $10 \mathrm{IUI} / \mathrm{IE} / \mathrm{U}$ & $\mathrm{R}$ & $\mathrm{S}$ & $\mathrm{S}$ & $\mathrm{S}$ & $\mathrm{S}$ & $\mathrm{S}$ \\
Ormetoprim & $1.25 \mu \mathrm{g}$ & $\mathrm{S}$ & $\mathrm{S}$ & $\mathrm{S}$ & $\mathrm{S}$ & $\mathrm{S}$ & $\mathrm{S}$ \\
Tetracycline & $30 \mu \mathrm{g}$ & $\mathrm{R}$ & $\mathrm{S}$ & $\mathrm{S}$ & $\mathrm{I}$ & $\mathrm{S}$ & $\mathrm{S}$ \\
Triple sulfa & $1.0 \mathrm{mg}$ & $\mathrm{S}$ & $\mathrm{S}$ & $\mathrm{S}$ & $\mathrm{S}$ & $\mathrm{S}$ & $\mathrm{S}$ \\
Spectinomycin & $100 \mu \mathrm{g}$ & $\mathrm{S}$ & $\mathrm{S}$ & $\mathrm{S}$ & $\mathrm{S}$ & $\mathrm{S}$ & $\mathrm{S}$ \\
\hline
\end{tabular}

${ }^{*}$ Veterinary Diagnostic Laboratory (University of Arkansas, Division of Agriculture, Fayetteville, AR, USA).

R: resistant; I: intermediate; S: susceptible. 
TABLE 6: Effect of Bacillus spp. isolates in reducing Salmonella Typhimurium from crop and ceca of broiler chickens in an avian model.

\begin{tabular}{lcccc}
\hline Bacillus isolates & Crop \% reduction & Crop $\log 10$ reduction & Cecal tonsils \% reduction & Ceca log 10 reduction \\
\hline NP 122 & 15.8 & ND & 50 & $2.5^{*}$ \\
AM 0904 & 0 & ND & ND & 0 \\
RW 41 & 0 & ND & ND & 0 \\
B2 & 0 & ND & ND & 0 \\
AM 1109 A and B & 8.4 & $1.62^{*}$ & 15.8 & ND \\
AM 1109 A and B & 10 & 0.63 & $1.15^{*}$ \\
(6-7-week-old broilers) & & & \\
\hline
\end{tabular}

* Significantly different at $P<0.05$.

ND: not determined.

contamination by other microorganisms [44]. All strains grew at $15^{\circ} \mathrm{C}$ to $44^{\circ} \mathrm{C}$ at both times of incubation $2 \mathrm{~h}$ and $4 \mathrm{~h}$ (Table 4). All strains (vegetative cells) were also able to tolerate high osmotic concentrations of $\mathrm{NaCl}$ (Table 4). This examination gave an indication of the osmotolerance level of the Bacillus spp. strains. Bacterial cells cultured in a high salt concentration could have a loss of turgor pressure, which would then affect their physiology, enzyme activity, water activity, and metabolism [44].

3.4. Antibiotic Resistance. The antibiotic resistance and susceptibility of the seven Bacillus isolates to twelve antibiotics were analyzed. All isolates were resistant to bacitracin and sensitive to gentamycin, neomycin, ormetoprim, triple sulfa, and spectinomycin. The isolate AM0902 was also resistant to clindamycin, ceftiofur, novobiocin, penicillin, and tetracycline. The isolate RW 41 also showed resistance to erythromycin, clindamycin, ceftiofur, and novobiocin, to which B2 was resistant as well. An intermediate susceptibility was observed with AM0902 on erythromycin and with AM0904 on tetracycline (Table 5).

According to Bakari et al. [37], probiotic bacteria that show resistance to a specific antibiotic can be given at the time of antibiotic treatment. Because antibiotic resistant genes are generally carried on conjugative plasmids, they can be transferred to other bacteria [45] and could possibly result in antibiotic-resistant enteropathogenic bacteria. Therefore, it is also important to determine whether antibiotic-resistant genes are present on chromosomes or on plasmids [37].

3.5. Salmonella Typhimurium In Vivo Growth Inhibition. According to Dodgson and Romanov [46], chickens have been a valuable model for human diseases and genetic analysis. Several spore-forming Bacillus spp. have been shown to reduce food-borne pathogens using commercial products available in Europe [2].

Our results showed that some Bacillus isolates, more specifically the isolates NP122 and the combination of the isolates AM1109A with AM1109B, were able to significantly reduce $S T$ levels in the crop and in the ceca of broiler chickens (Table 6). The ability of Bacillus subtilis probiotic isolates in reducing Salmonella in chickens has been described previously by La Ragione and Woodward [47] and Vilá et al. [48].

Competitive exclusion of pathogens is a common hypothesis to explain the action of probiotics $[49,50]$. This process has been well demonstrated in Lactobacillus spp., and some evidence exists that Bacillus spp. may have the same mode of action [21]. Competitive exclusion includes the competition for receptor sites and nutrients and the production of antimicrobial substances such as bacteriocins, hydrogen peroxide, and volatile fatty acids $[49,51]$. Another potential mechanism of action of probiotics, that has received a lot of attention, is the modulation of the host's immune system [51]. According to $\mathrm{Ng}$ et al. and Rupa and Mine [51, 52], the probiotics alter immune functions in humans and animals by interacting with various receptors. An example is in the treatment of inflammatory bowel disease with probiotics in humans. Following probiotic treatment there are improvement of the epithelial and mucosal barrier function, modulation of the intestinal microbiota, and a direct effect on immune cells of both innate and adaptive immune systems. Despite the beneficial effects of the probiotics observed, in vivo mechanisms of action have not been clearly elucidated and will be a significant area for future research [53]. Several studies have shown that either live vegetative cells or spores of some Bacillus isolates can prevent colon carcinogenesis [18] or release antimicrobial substances against bacteria, such as Staphylococcus aureus, Enterococcus faecium, and Clostridium difficile [19]. These results supported the evidence of colonization and antimicrobial activity of Bacillus spp. as probiotic bacteria. Therefore, products containing Bacillus spores are used commercially as probiotics [1, 21, 22, 54-59].

\section{Conclusion}

Bacterial spore formers, especially of the genus Bacillus, are present in current probiotic products that have been shown to prevent gastrointestinal diseases in animals and humans. These probiotic-based spores have been shown to have many applications such as treating immunosuppressive and antibiotic-associated diarrhea. The results obtained in this study showed the tolerance of probiotic Bacillus spp. strains in different physiological conditions as well as the inhibition of Salmonella Typhimurium. Moreover, the methods used to screen isolates may be important in the evaluation of Bacillus spp. for use as probiotics for humans and animals.

\section{References}

[1] H. A. Hong, H. D. Le, and S. M. Cutting, "The use of bacterial spore formers as probiotics," FEMS Microbiology Reviews, vol. 29, no. 4, pp. 813-835, 2005. 
[2] A. Jadamus, W. Vahjen, K. Schäfer, and O. Simon, "Influence of the probiotic strain Bacillus cereus var. toyoi on the development of enterobacterial growth and on selected parameters of bacterial metabolism in digesta samples of piglets," Journal of Animal Physiology and Animal Nutrition, vol. 86, no. 1-2, pp. 42-54, 2002.

[3] H. Kasper, "Protection against gastrointestinal diseasespresent facts and future developments," International Journal of Food Microbiology, vol. 41, no. 2, pp. 127-131, 1998.

[4] R. D. Sleatorand and C. Hill, "New frontiers in probiotic research," Letters in Applied Microbiology, vol. 46, pp. 143-147, 2008.

[5] R. D. Rolfe, "The role of probiotic cultures in the control of gastrointestinal health," Journal of Nutrition, vol. 130, pp. 396S402S, 2000 .

[6] C. H. Liu, C. H. Chiu, S. W. Wang, and W. Cheng, "Dietary administration of the probiotic, Bacillus subtilis E20, enhances the growth, innate immune responses, and disease resistance of the grouper, Epinephelus coioides," Fish \& Shellfish Immunology, vol. 33, no. 4, pp. 699-706, 2012.

[7] K. Kobayashi, "Chemotherapy-induced diarrhea," Cancer \& Chemotherapy, vol. 30, no. 6, pp. 765-771, 2003.

[8] D. M. F. Savarese, G. Savy, L. Vahdat, P. E. Wischmeyer, and B. Corey, "Prevention of chemotheraphy and radiation toxicity with glutamine," Cancer Treatment Reviews, vol. 29, no. 6, pp. 501-513, 2003.

[9] C. McGough, C. Baldwin, G. Frost, and H. J. N. Andreyev, "Role of nutritional intervention in patients treated with radiotherapy for pelvic malignancy," British Journal of Cancer, vol. 90, no. 12, pp. 2278-2287, 2004.

[10] L. M. Noriega, P. van der Auwera, D. Daneau, F. Meunier, and M. Aoun, "Salmonella infections in a cancer center," Supportive Care in Cancer, vol. 2, no. 2, pp. 116-122, 1994.

[11] J. Delaloye, G. Merlani, C. Petignat et al., "Nosocomial nontyphoidal salmonellosis after antineoplastic chemotherapy: reactivation of asymptomatic colonization?" European Journal of Clinical Microbiology and Infectious Diseases, vol. 23, no. 10, pp. 751-758, 2004.

[12] E. I. Benchimol and D. R. Mack, "Probiotics in relapsing and chronic diarrhea," Journal of Pediatric Hematology/Oncology, vol. 26, no. 8, pp. 515-517, 2004.

[13] M. W. Hull and P. L. Beck, "Clostridium difficile-associated colitis," Canadian Family Physician, vol. 50, pp. 1536-1545, 2004.

[14] D. Czerucka and P. Rampal, "Experimental effects of Saccharomyces boulardii on diarrheal pathogens," Microbes and Infection, vol. 4, no. 7, pp. 733-739, 2002.

[15] D. Czerucka, S. Dahan, B. Mograbi, B. Rossi, and P. Rampal, "Saccharomyces boulardii preserves the barrier function and modulates the signal transduction pathway induced in enteropathogenic Escherichia coli-infected T84 cells," Infection and Immunity, vol. 68, no. 10, pp. 5998-6004, 2000.

[16] N. K. Lee, J. S. Park, E. Park, and H. D. Paik, "Adherence and anticarcinogenic effects of Bacillus polyfermenticus SCD in the large intestine," Letters in Applied Microbiology, vol. 44, no. 3, pp. 274-278, 2007.

[17] S. V. Malkov, V. V. Markelov, G. Y. Polozov, B. I. Barabanschikov, A. Y. Kozhevnikov, and M. V. Trushin, "Significant delay of lethal outcome in cancer patients due to peroral administration of Bacillus oligonitrophilus KU-1," TheScientificWorldJournal, vol. 6, pp. 2177-2187, 2006.
[18] E. Park, G. I. Jeon, J. S. Park, and H. D. Paik, “A probiotic strain of Bacillus polyfermenticus reduces DMH induced precancerous lesions in F344 male rat," Biological and Pharmaceutical Bulletin, vol. 30, no. 3, pp. 569-574, 2007.

[19] L. O’Mahony, M. Feeney, S. O’Halloran et al., "Probiotic impact on microbial flora, inflammation and tumour development in IL-10 knockout mice," Alimentary Pharmacology and Therapeutics, vol. 15, no. 8, pp. 1219-1225, 2001.

[20] M. C. Urdaci, P. Bressollier, and I. Pinchuk, "Bacillus clausii probiotic strains: antimicrobial and immunomodulatory activities," Journal of clinical gastroenterology, vol. 38, no. 6, pp. S86-S90, 2004.

[21] T. M. Barbosa, C. R. Serra, R. M. La Ragione, M. J. Woodward, and A. O. Henriques, "Screening for Bacillus isolates in the broiler gastrointestinal tract," Applied and Environmental Microbiology, vol. 71, no. 2, pp. 968-978, 2005.

[22] L. H. Duc, H. A. Hong, T. M. Barbosa, A. O. Henriques, and S. M. Cutting, "Characterization of Bacillus probiotics available for human use," Applied and Environmental Microbiology, vol. 70, no. 4, pp. 2161-2171, 2004.

[23] P. Permpoonpattana, H. A. Hong, R. Khaneja, and S. M. Cutting, "Evaluation of Bacillus subtilis strains as probiotics and their potential as a food ingredient," Beneficial Microbes, vol. 3, no. 2, pp. 127-135, 2012.

[24] L. H. Duc, H. A. Hong, and S. M. Cutting, "Germination of the spore in the gastrointestinal tract provides a novel route for heterologous antigen delivery," Vaccine, vol. 21, no. 27-30, pp. 4215-4224, 2003.

[25] L. H. Duc, H. A. Hong, N. Fairweather, E. Ricca, and S. M. Cutting, "Bacterial spores as vaccine vehicles," Infection and Immunity, vol. 71, no. 5, pp. 2810-2818, 2003.

[26] T. T. Hoa, L. H. Duc, R. Isticato et al., "Fate and dissemination of Bacillus subtilis spores in a murine model," Applied and Environmental Microbiology, vol. 67, no. 9, pp. 3819-3823, 2001.

[27] G. Casula and S. M. Cutting, "Bacillus probiotics: spore germination in the gastrointestinal tract," Applied and Environmental Microbiology, vol. 68, no. 5, pp. 2344-2352, 2002.

[28] R. E. Wolfenden, N. R. Pumford, M. J. Morgan et al., "Evaluation of a screening and selection method for bacillus isolates for use as effective direct-fed microbials in commercial poultry," International Journal of Poultry Science, vol. 9, no. 4, pp. 317-323, 2010.

[29] S. E. Gilliland, T. E. Staley, and L. J. Bush, "Importance of bile tolerance of Lactobacillus acidophilus used as a dietary adjunct," Journal of dairy science, vol. 67, no. 12, pp. 3045-3051, 1984.

[30] G. Tellez, C. E. Dean, D. E. Corrier, J. R. Deloach, L. Jaeger, and B. M. Hargis, "Effect of dietary lactose on cecal morphology, $\mathrm{pH}$, organic acids, and Salmonella enteritidis organ invasion in Leghorn chicks," Poultry Science, vol. 72, no. 4, pp. 636-642, 1993.

[31] SAS Institute Inc. 2002-2003, Version 9.1, Carey, NC, USA.

[32] J. Zar, Biostatistical Analysis, Prentice-Hall, 2nd edition, 1984.

[33] N. A. Logan and R. C. W. Berkeley, "Identification of Bacillus strains using the API system," Journal of General Microbiology, vol. 130, no. 7, pp. 1871-1882, 1984.

[34] R. D. Wagner, D. D. Paine, and C. E. Cerniglia, "Phenotypic and genotypic characterization of competitive exclusion products for use in poultry," Journal of Applied Microbiology, vol. 94, no. 6, pp. 1098-1107, 2003.

[35] R. Havenaar, B. T. Brink, and J. H. J. Huis Veld, "Selection of strains for probiotic use," in Probiotics, the Scientific Basis, R. 
Fuller, Ed., vol. 1, pp. 209-224, Chapman and Hall, London, UK, 1992.

[36] S. M. Kristoffersen, S. Ravnum, N. J. Tourasse, O. A. Økstad, A. B. Kolstø, and W. Davies, "Low concentrations of bile salts induce stress responses and reduce motility in Bacillus cereus ATCC 14570," Journal of Bacteriology, vol. 189, no. 14, pp. 53025313, 2007.

[37] D. Bakari, N. L. Tatsadjieu, A. Mbawala, and C. M. Mbofung, "Assessment of physiological properties of some lactic acid bacteria isolated from the intestine of chickens use as probiotics and antimicrobial agents against enteropathogenic bacteria," Innovative Romanian Food Biotechnology, vol. 8, pp. 33-40, 2011.

[38] M. Begley, C. G. M. Gahan, and C. Hill, "The interaction between bacteria and bile," FEMS Microbiology Reviews, vol. 29, no. 4, pp. 625-651, 2005.

[39] S. B. Hernández, I. Cota, A. Ducret, L. Aussel, and J. Casadesús, "Adaptation and preadaptation of Salmonella enterica to bile," PLoS Genetics, vol. 8, no. 1, pp. 1-15, 2012.

[40] M. Du Toit, C. M. A. P. Franz, L. M. T. Dicks et al., "Characterisation and selection of probiotic lactobacilli for a preliminary minipig feeding trial and their effect on serum cholesterol levels, faeces $\mathrm{pH}$ and faeces moisture content," International Journal of Food Microbiology, vol. 40, no. 1-2, pp. 93-104, 1998.

[41] H. Tanaka, K. Doesburg, T. Iwasaki, and I. Mierau, "Screening of lactic acid bacteria for bile salt hydrolase activity," Journal of Dairy Science, vol. 82, no. 12, pp. 2530-2535, 1999.

[42] C. Dunne, L. O’Mahony, L. Murphy et al., "In vitro selection criteria for probiotic bacteria of human origin: correlation with in vivo findings," American Journal of Clinical Nutrition, vol. 73, no. 2, pp. 386S-392S, 2001.

[43] A. C. Ouwehand, S. Salminen, and E. Isolauri, "Probiotics: an overview of beneficial effects," Antonie van Leeuwenhoek, vol. 82, no. 1-4, pp. 279-289, 2002.

[44] C. Ibourahema, R. D. Dauphin, D. Jacqueline, and P. Thonart, "Characterization of lactic acid bacteria isolated from poultry farms in Senegal," African Journal of Biotechnology, vol. 7, no. 12, pp. 2006-2012, 2008.

[45] P. M. Bennett, "Plasmid encoded antibiotic resistance: acquisition and transfer of antibiotic resistance genes in bacteria," British Journal of Pharmacology, vol. 153, no. 1, pp. S347-S357, 2008.

[46] J. B. Dodgson and M. N. Romanov, "Use of chicken models for the analysis of human disease," Current Protocols in Human Genetics, vol. 15, unit 15.5, pp. 15.5.1-15.5.12, 2004.

[47] R. M. La Ragione and M. J. Woodward, "Competitive exclusion by Bacillus subtilis spores of Salmonella enterica serotype Enteritidis and Clostridium perfringens in young chickens," Veterinary Microbiology, vol. 94, no. 3, pp. 245-256, 2003.

[48] B. Vilà, A. Fontgibell, I. Badiola et al., "Reduction of Salmonella enterica var. Enteritidis colonization and invasion by Bacillus cereus var. toyoi inclusion in poultry feeds," Poultry Science, vol. 88, no. 5, pp. 975-979, 2009.

[49] J. A. Patterson and K. M. Burkholder, "Application of prebiotics and probiotics in poultry production," Poultry Science, vol. 82, no. 4, pp. 627-631, 2003.

[50] T. D. Leser, A. Knarreborg, and J. Worm, "Germination and outgrowth of Bacillus subtilis and Bacillus licheniformis spores in the gastrointestinal tract of pigs," Journal of Applied Microbiology, vol. 104, no. 4, pp. 1025-1033, 2008.

[51] S. C. Ng, A. L. Hart, M. A. Kamm, A. J. Stagg, and S. C. Knight, "Mechanisms of action of probiotics: recent advances," Inflammatory Bowel Diseases, vol. 15, no. 2, pp. 300-310, 2009.
[52] P. Rupa and Y. Mine, "Recent advances in the role of probiotics in human inflammation and gut health," Journal of Agricultural and Food Chemistry, vol. 60, pp. 8249-8256, 2012.

[53] S. C. Corr, Y. Li, C. U. Riedel, P. W. O’Toole, C. Hill, and C. G. M. Gahan, "Bacteriocin production as a mechanism for the antiinfective activity of Lactobacillus salivarius UCC118," Proceedings of the National Academy of Sciences of the United States of America, vol. 104, pp. 7617-7621, 2007.

[54] A. Anadón, M. R. Martinez-Larranaga, and M. Aranzazu Martinez, "Probiotics for animal nutrition in the european union regulation and safety assessment," Regulatory Toxicology and Pharmacology, vol. 45, no. 1, pp. 91-95, 2006.

[55] H. A. Hong, J. M. Huang, R. Khaneja, L. V. Hiep, M. C. Urdaci, and S. M. Cutting, "The safety of Bacillus subtilis and Bacillus indicus as food probiotics," Journal of Applied Microbiology, vol. 105, no. 2, pp. 510-520, 2008.

[56] C. A. McNulty, P. Boyle, T. Nichols, P. Clappison, and P. Davey, "The public's attitudes to and compliance with antibiotics," The Journal of Antimicrobial Chemotherapy, vol. 60, supplement 1, pp. i63-i68, 2007.

[57] I. G. Osipova, N. A. Makhailova, I. B. Sorokulova, E. A. Vasil'eva, and A. A. Gaiderov, "Spore probiotics," Zhurnal Mikrobiologii Epidemiologii i Immunobiologii, vol. 3, no. 3, pp. 113-119, 2003.

[58] P. Williams, "Bacillus subtilis: a shocking message from a probiotic," Cell Host and Microbe, vol. 1, no. 4, pp. 248-249, 2007.

[59] W. A. M. Wolken, J. Tramper, and M. J. Van Der Werf, "What can spores do for us?" Trends in Biotechnology, vol. 21, no. 8, pp. 338345, 2003. 

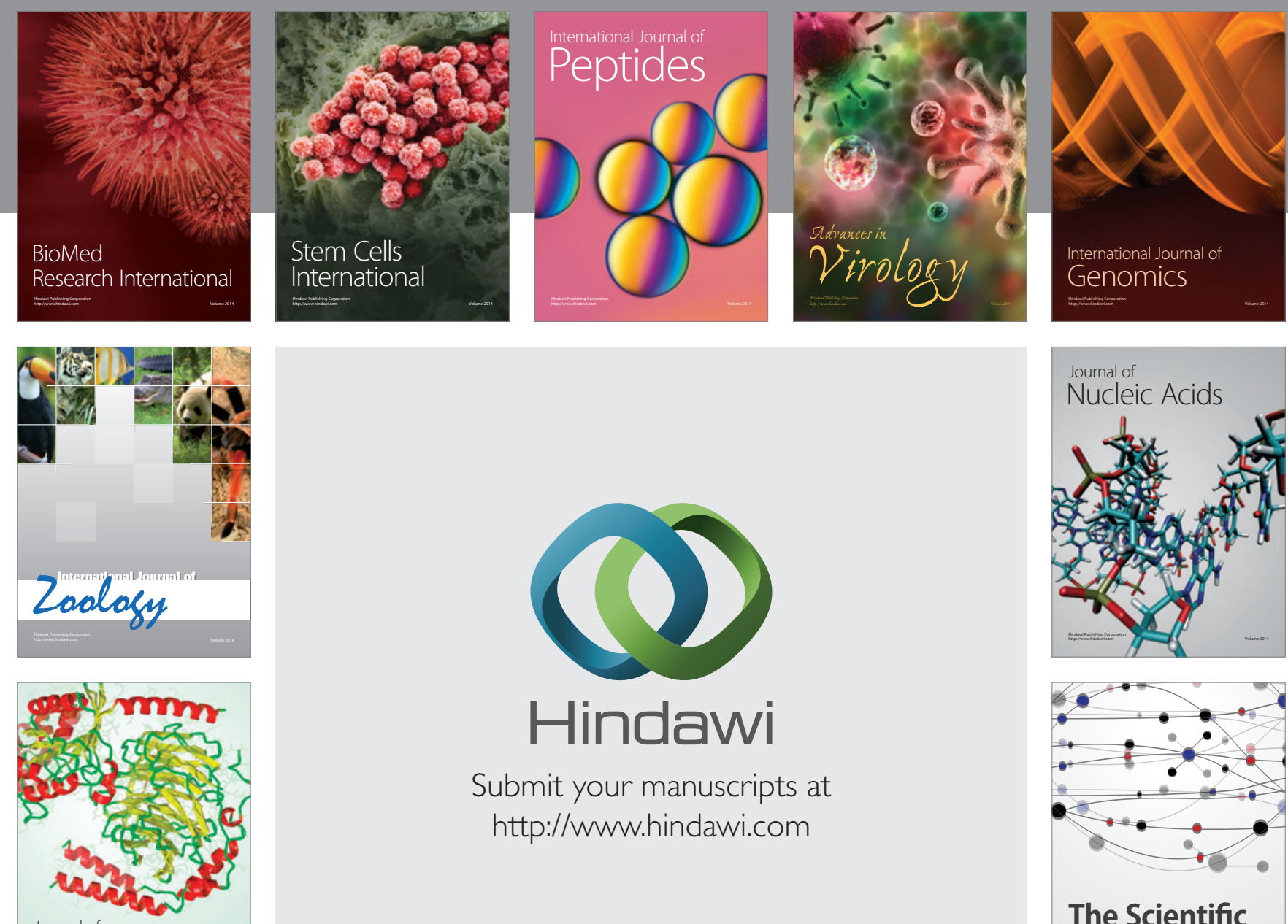

Submit your manuscripts at

http://www.hindawi.com

Journal of
Signal Transduction
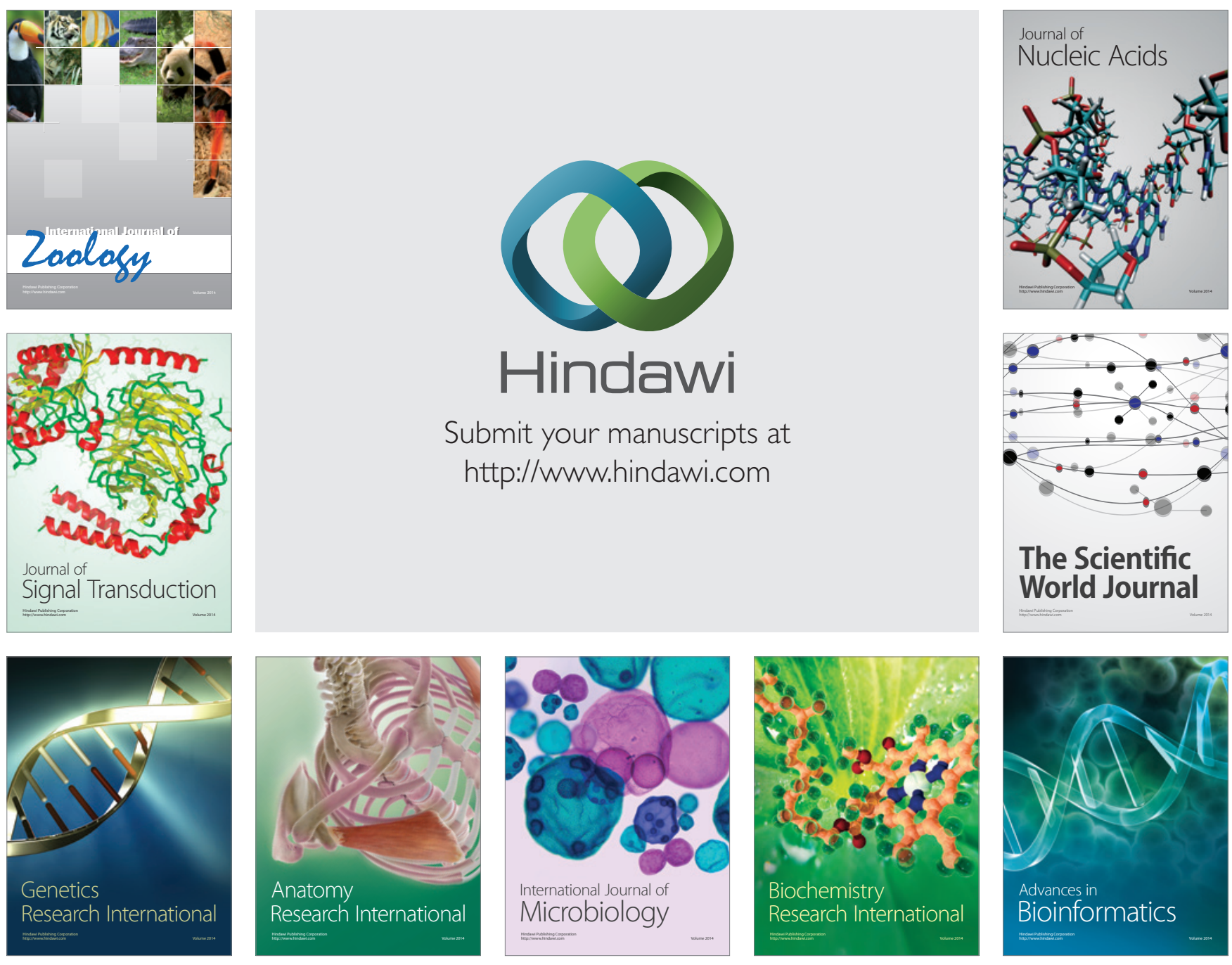

The Scientific World Journal
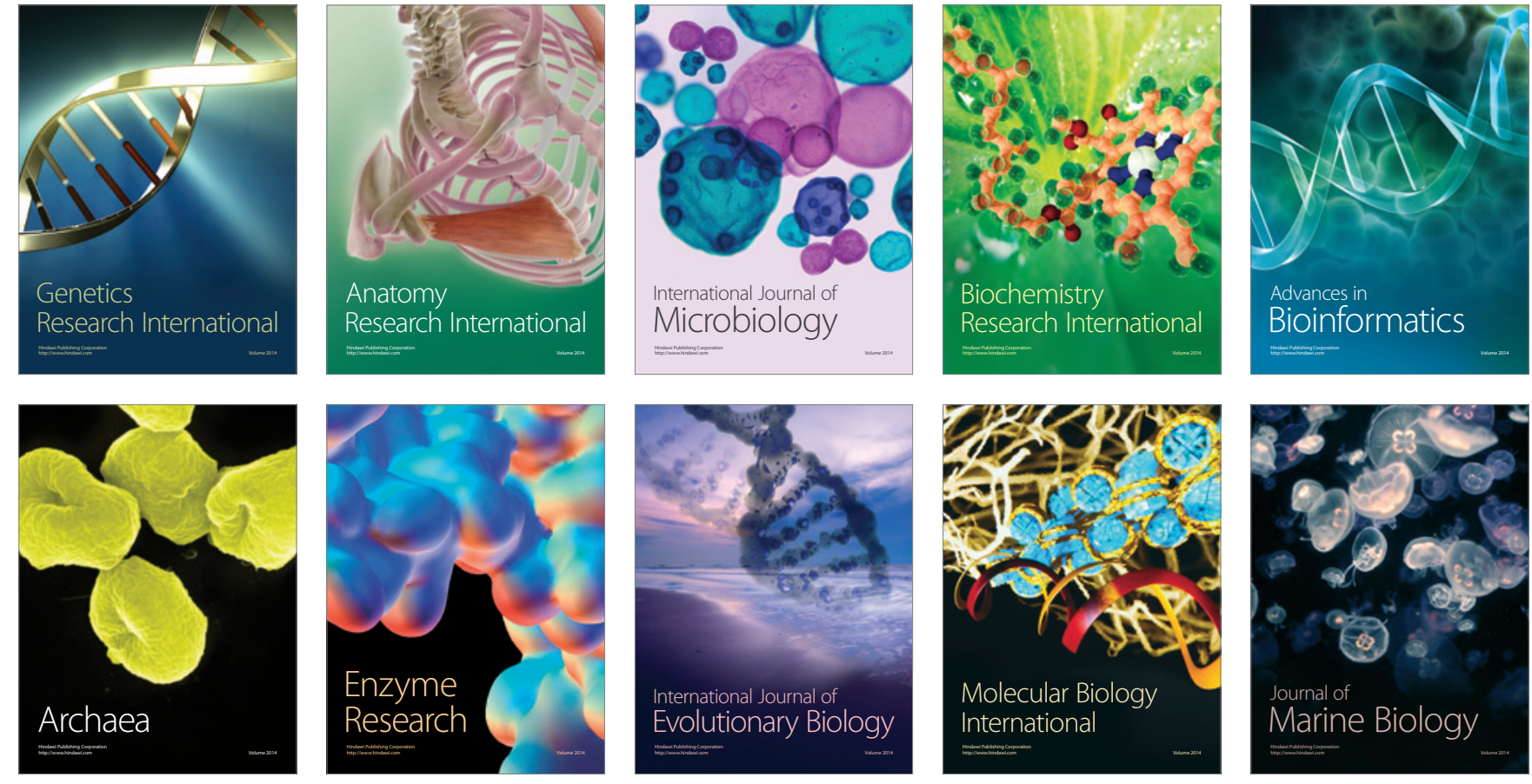